on the chromosomes of the salivary glands in Drosophila in relation to the problems of mutation and genetics, published in Genetics and the Journal of Heredity in 1934; John J. Carty Medal, and award for the advancement of science, consisting of a gold medal, bronze replica, certificate and 3,000 dollars, awarded to Sir William Bragg, of the Royal Institution, London, for his fundamental work in $\mathrm{X}$-ray crystal analysis; he has shown how to reveal the constitution of crystalline forms and accurately measure them, and his studies have given birth to a new tool which is bringing to light important facts regarding such complex structures as the larger organic molecules.

\section{U.S. National Academy of Sciences: Elections}

AT the annual meeting of tho National Academy of Sciences, Dr. Frank B. Jewett, president of the Bell Telephone Laboratories, was elected president for a term of four years, to succeed Dr. Frank $\mathbf{R}$. Lillie, emeritus professor of zoology of the University of Chicago, who will retire on June 30. The following were elected members of the Academy: Gregory Breit, professor of physics, University of Wisconsin; Detlev Wulf Bronk, Johnson professor of biophysics and director of the Johnson Foundation, University of Pennsylvania; William Bosworth Castle, associate professor of medicine, Harvard Medical School, director of the Thorndike Memorial Laboratory, Boston City Hospital ; Frederick Gardner Cottrell, president, Research Associates, Incorporated, Washington, D.C., consulting chemist, Bureau of Chemistry and Soils; Frederick Parker Gay, professor of pathology and bacteriology, College of Physicians and Surgeons, Columbia University; Albert Baird Hastings, Hamilton Kuhn professor of biochemistry, Harvard University; Vladimir Nikolaevich Ipatieff, research director of the Universal Oil Products Company, professor of chemistry, Northwestern University; Merkel Henry Jacobs, professor of general physiology, University of Pennsylvania; Zay Jeffries, General Electric Company, Cleveland, Ohio ; Donald Forsha Jones, geneticist, Connecticut Agricultural Experiment Station, New Haven; George Bogdan Kistiakowsky, professor of chemistry, Harvard University; Warren Judson Mead, pro. fessor and head of the department of geology, Massachusetts Institute of Technology; Oscar Riddle, investigator, department of genetics, Station for Experimental Evolution, Carnegie Institution, Cold Spring Harbor, N.Y. ; Adolph Hans Schultz, associate professor of physical anthropology, School of Medicine, the Johns Hopkins University; Philip Edward Smith, professor of anatomy, College of Physicians and Surgeons, Columbia University.

THE following were elected foreign associates: Sir Joseph Barcroft, professor of physiology, University of Cambridge; Sir William Bragg, director, Royal Institution of Great Britain and Fullerian professor of chemistry and director of the Davy Faraday Research Laboratory; Dr. F. A. Vening Meinesz, professor of geodesy and cartography, the University of Utrecht.

\section{Franklin Medals}

Frankurn Medals have been awarded by the Franklin Institute, Philadelphia, Pa., as follows : Edwin Hubble, Mount Wilson Observatory, Carnegie Institution of Washington, Pasadena, "In recognition of his extensive study of the nebulæ, particularly those outside our galaxy, as a result of which the dimensions of observed space have been greatly increased" ; Albert Sauveur (posthumously), professor emeritus of metallurgy and metallography, Harvard University, "In recognition of his outstanding work in the science of metallography and of his many contributions to this branch of metallurgy which have been in a large measure responsible for changing the heat treatment of steel from an art to a science".

\section{Rare Frankliniana}

VISITORS to the recent exhibition of "Frankliniana" at New York City's Grolier Club (March 16-April 16) were impressed alike by the incomprehensible versatility of Benjamin Franklin's genius and by the fascinating rarity of many of the exhibits displayed. Printer, journalist, statesman, advocate of inoculation, inventor, and the most widely travelled American of his day, Franklin crossed the Atlantic Ocean eight times. That he was not unaware of the perils of travel is revealed by an obsolete will "written by my own hand while waiting for a passage to England" in 1757. By his classic kite experiment in 1748 he proved the identity of lightning and electricity, and his book "Experiments and Observations on Electricity", London, 1751, with a preface by his physician and friend Dr. John Fothergill, carried his fame over the civilized world. "Some Account of the Pennsylvania Hospital", Philadelphia, 1754, recalls that Franklin was instmumental in founding what is regarded as the oldest hospital, in the modern sense of the term, in the present United States. He served as the first clerk to the board of management and later as president. "Proposals for Promoting useful Knowledge among the British Plantations", 1743, is believed to be the earliest suggestion in printed form for an American Philosophical Society, to which the author offers his services as secretary. The pamphlet shown is de scribed as one of two copies known. His first book, "Dissertation on Liberty and Necessity, Pleasure and Pain", London, 1725, the young Franklin grew to dislike so violently that he destroyed all remaining copies except one. Other exhibits included a selection of his famous almanacs, so rare to-day, though originally issued in editions of 10,000 copies.

\section{Chaston Chapman Gift to the University of Leeds}

IN 1933 Mrs. Chaston Chapman presented to the University of Leeds her late husband's extensive working library of modern books on chemistry, together with complete runs of a large number of periodicals. Mrs. Chaston Chapman has now presented his collection of works on alchemy to the University of Leeds, where they are housed in the Brotherton Library. There is a small section of French books and a more extensive section of 
English books. Noteworthy among the latter are "The Mirror of Alchimy, Composed by the thricefamous and learned Fryer, Roger Bachon", London, 1597; the rare "Secrets Reveal'd : or, An open entrance to the Shut-Palace of the King : Containing The greatest Treasure in Chymistry, Never yet so plainly Discovered", 1669 ; Plat, "The Jewel House of Art and Nature", 1653 ; and many other rare works. Translations into English include Geber, "The Works of Geber, the most famous Arabian prince and philosopher", 1678; Beguin, "Tyrocinium Chymicum", 1669 ; Paracelsus, "The Chymical Transmutation of Metals", 1657 ; Glauber, "The Golden Ass Well Managed", 1670; Gesner, "The newe Iewell of Health", 1576 ; Le Febure, "A compleat Body of Chymistry", 1670; the 1677 and 1686 translations of Lemery, "A Course of Chymistry" and "New Curiosities in Art and Nature", 1711, by the same author.

OF large folios from the Chaston Chapman collection there are good copies of the works of Agricola, Cardanus, Josephus, Lucretius, Manget, Paracelsus, Pettus, Petronius, Sennert, van Helmont, and others. There are some two hundred works by German and Dutch seventeenth-century authors. Becher and Stahl, the two founders of the phlogiston theory, are well represented. There are also certain editions of the strange work "De Secretis", composed by Alexis of Piedmont, a contrite revelation to the world of the secret remedies that might have saved a patient's life. Special attention was also paid by Mr. Chaston Chapman to Black, Boerhaave, Boyle, Newton, and Priestley, and there is an interesting series of old and modern books on brewing and fermentation, commencing with "A Perfite platforme of a Hoppe Garden", 1578. A whole case is devoted to the Royal Society, with the first, second, and fourth editions of Sprat's history of the Society. With the single exception of Lord Brotherton's books, this carefully selected library is the most valuable collection of rare books that the University has ever received.

\section{Bledisloe Medal for Native Agriculture}

IN the recently issued report of the RhodesiaNyasaland Royal Commission (see Nature, May 20, p. 829) stress is laid by members of the Commission in the expression of their individual views regarding certain matters, on the importance of the development of the native for the future of all three territories alike. In this development, agriculture and native husbandry are assigned the foremost place, more especially in the two protectorates, of which the future prosperity can only be based upon agriculture. In the memorandum appended by the chairman, Lord Bledisloe, and Mr. P. A. Cooper, it is said that "Education is a crying need of the African, but its foundation should, in his case, be knowledge of the land and its proper treatment on the one hand and of the basic principles of nutrition and hygiene on the other. These lessons are even more vital to his true welfare than reading and arithmetic, and should take precedence of them." They go on to point out that they are inclined to the view that both land and labour are at present wasted, adding a caution against dogmatic pronouncement that large areas of territory are permanently unsuited to human occupation or economic utilization. In order to encourage the development of the native as agriculturist, Lord Bledisloe has now instituted a silver medal for presentation annually in appropriate numbers to the chiefs of the various tribes of Southern Rhodesia who have done most to induce their tribesmen to adopt improved methods of husbandry. The medal bears on its obverse the figure of a native Afrikander bull with the inscription "Southern Rhodesia Mutungamiri Umtungameli", the Bantu and Sindabele terms for leader or guide. The reverse bears an ear of maize and the inscription "The Bledisloe Medal for the Advancement of Native Husbandry".

\section{Treasure at Delphi}

A DISCOVERY, which would seem to be remarkable even in the annals of Mediterranean archæology for the quantity of objects of gold brought to light, is reported from Delphi, where excavations have been in progress under Prof. Delacotte on behalf of the French School of Archæology at Athens during the past two years. A dispatch from the correspondent of The Times in the issue of May 10 states that in the course of raising and relaying the pavement of the Sacred Way from the eastern side of the Sanctuary in the direction of the Temple of Apollo in a search for inscriptions, a cavity has been found in the centre of the Stoa of the Athenians, in which was a mass of objects, covered with dust and ashes, and including a large number of gold articles. Of these the most important is the gold overlay of a chrys. elephantine statue, of which the ivory has been carbonized. The robe, diadem, ear-rings, bracelets, curls, heads and flowers, which formed the decorations of the robe, and the girdle, all in gold, have been recovered. A bronze statuette holding a receptacle for the burning of aromatic woods, which is complete and of remarkable workmanship, is dated at 500 в.c. In addition, there is a quantity of material in clay, copper and bronze. Expert opinion at present is that the finds show evidence of Oriental influence, possibly originating from the Greek cities of Asia Minor. A further discovery is a second cavity, found in working in a northerly direction from the Sacred Way, which was full of bronze and copper objects, all much encrusted, but otherwise in good preservation. Here also Eastern influence is discerned.

\section{Television and the Provinces}

Mr. C. O. Stanley, chairman of the Television Development Committee of the Radio Manufacturers Association, spoke at Manchester on May 13 outlining the great progress recently made with television. He pointed out that it is necessary to have a universal service for the whole of Great Britain in order to enable manufacturers to develop the export industry. The first step is to extend television to the provinces. While the mentality produced by experimental tele- 